\title{
Utilization of Foeniculum vulgare in herbal candy preparation and analysing its effect on the physico-chemical and sensory properties
}

\author{
Rekha Kailey ${ }^{1}$, Kajal Dhawan ${ }^{1}$, Prasad Rasane ${ }^{1,2, *}$, Jyoti Singh ${ }^{1}$, \\ Sawinder Kaur ${ }^{1}$, Bhanu Pratap Singh ${ }^{3}$, Navneet Kaur ${ }^{4}$ and Damanpreet Kaur ${ }^{1}$ \\ ${ }^{1}$ Food Technology and Nutrition, School of Agriculture, Lovely Professional University, Phagwara 144 411, India \\ ${ }^{2}$ Department of Dairy Science and Food Technology, Banaras Hindu University, Varanasi 221005 , India \\ ${ }^{3}$ Perfetti Van Melle India Pvt Ltd, Manesar, Gurugram 122 051, India \\ ${ }^{4}$ School of Engineering Technology and Applied Science, Centennial College, Toronto, Canada
}

Foeniculum vulgare, also known as fennel, is a medicinal herb belonging to the Apiaceae (Umbelliferae) family. The present study examined the effect of different processing techniques (sun- and tray-drying, and roasting) on fennel seeds and aimed to find the best method for incorporation of powder in the formulation of hard candy to deliver phytochemicals and bioactive compounds that it possesses, thus rendering health benefits. The proximate and physico-chemical evaluation of fennel-seed powder showed that sundrying is the most effective technique. It retains most of the nutrients of fennel seeds. It also requires less technical know-how, no sophisticated equipment and is economical. Thus, sun-dried fennel-seed powder was used in the formulation of hard candy and DF11 (5\% fennel-seed powder) was the best formulation deemed to be optimized with physico-chemical and sensory characteristics that were found acceptable.

Keywords: Fennel seeds, herbal candy, processing techniques, physico-chemical and sensory properties.

FOENICULUM VULGARE (fennel) is a medicinal herb belonging to the Apiaceae (Umbelliferae) family. In ancient times fennel was known as 'maddhurika', in early Sanskrit writings ${ }^{1,2}$. It is cultivated in India since 2000 BC (ref. 3). Plant parts and roots are used as edible herb and seeds as spice ${ }^{4}$. About $100 \mathrm{~g}$ edible fennel seeds contain on average $8.8 \mathrm{~g}$ water, $15.8 \mathrm{~g}$ protein, $14.9 \mathrm{~g}$ fat, $36.6 \mathrm{~g}$ carbohydrates, $15.7 \mathrm{~g}$ fibre and $8.2 \mathrm{~g}$ ash $(1.2 \mathrm{~g} \mathrm{Ca}$, $19 \mathrm{mg} \mathrm{Fe}, 1.7 \mathrm{~g} \mathrm{~K}, 385 \mathrm{mg} \mathrm{Mg}, 88 \mathrm{mg} \mathrm{Na}, 487 \mathrm{mg} \mathrm{P}$ and $28 \mathrm{mg} \mathrm{Zn})$, vitamin A (135 IU), niacin (6 mg), thiamine $(0.41 \mathrm{mg})$ and riboflavin $(0.35 \mathrm{mg})$, with energy value about $1440 \mathrm{~kJ}$ (ref. 3).

Fennel has been a part of the traditional medicine since ancient times; it has been used in diseases and disorders of digestive, endocrine, reproductive and respiratory systems. It is widely used by lactating mothers as it is a

*For correspondence. (e-mail: rasaneprasad@gmail.com) common galactagogue (chemical agents that help in increased production of milk). It is also used in pharmaceuticals because of its antimicrobial, antiviral, antiinflammatory, antimutagenic, antispasmodic, antithrombotic, antitumour, cardiovascular, chemomodulatory, hepatoprotective, diuretic, analgesic, hypoglycaemic and memory-boosting properties ${ }^{5-7}$.

It is found that from pre-school children to the elderly, all are fond of confectionery products. Confectionery includes sugar-based products like sweets, candies, toffees, chocolates, etc. Therefore, in the present study we analyse the effect of processing conditions on the physico-chemical properties of fennel, to chose an appropriate process for preparing a fennel-based herbal candy.

\section{Materials and methods}

The raw material, viz. fennel (Foeniculum vulgare, variety Hisar Swarup) was procured from the experimental farms of Lovely Professional University (LPU), Phagwara, Punjab, while table sugar was procured from the local market in Jalandhar, and liquid glucose from Glushan Polyols Ltd, Gujarat.

\section{Drying techniques}

For sun-drying, fennel seeds were kept under sunlight $\left(30-35^{\circ} \mathrm{C}\right)$ for 2 days ( $12 \mathrm{~h}$ of sunlight) and ground to make a powder. For tray-drying, fennel seeds were kept in a tray drier (Narang Scientific and Electronic Equipment, Pvt Ltd, New Delhi) at $55^{\circ} \mathrm{C}$ for $3 \mathrm{~h}$ until the final three consecutive readings were taken. For roasting, fennel seeds were roasted at $75-80^{\circ} \mathrm{C}$ for $30 \mathrm{~min}$.

\section{Proximate analysis}

Moisture content: Sample (5 g) was weighed accurately into a cooled and tare glass petri placed. The sample was 


\section{RESEARCH ARTICLES}

heated in hot-air oven maintained at $105^{\circ} \pm 2^{\circ} \mathrm{C}$ for $3 \mathrm{~h}$. Next, the dish was transferred to desiccators, cooled and weighed ${ }^{8}$. Moisture content was calculated as

$$
\text { Moisture content }=\frac{\left(W_{1}-W_{2} \times 100\right)}{W_{1}-W}
$$

where $W$ is the weight of the empty dish $(\mathrm{g}), W_{1}$ the weight of the dish with the sample $(\mathrm{g})$ and $W_{2}$ is the final weight of the dish $(\mathrm{g})$.

Fat content: This was calculated using Soxhlet extraction method ${ }^{8}$. Sample $(5 \mathrm{~g})$ was taken in a thimble and extracted with petroleum ether in Soxhlet extraction apparatus for $6-8 \mathrm{~h}$ in a pre-weighed round-bottom flask. The poured content was heated at $70^{\circ} \mathrm{C}$ for $1 \mathrm{~h}$ and then the temperature was raised to $140^{\circ} \mathrm{C}$ for the next $1 \mathrm{~h}$. After heating, the remaining content was evaporated at $102^{\circ} \mathrm{C}$ till final weight was analysed. The content was calculated using the formula

$$
\text { Fat }(\%)=\frac{W_{2}-W_{1}}{S} \times 100
$$

where $W_{1}$ is the weight of the empty silica crucible $(\mathrm{g})$, $W_{2}$ the weight of the silica crucible with ash $(\mathrm{g})$ and $S$ is the weight of the sample $(\mathrm{g})$.

Protein content: This was determined using Kjeldhal method. Weighed sample $(0.3 \mathrm{~g})$ was digested along with concentrated sulphuric acid $(10 \mathrm{ml})$ and digestion mixture ( $4 \mathrm{~g}$ potassium sulphate and $1 \mathrm{~g}$ copper sulphate) in a Kjeldhal digestion flask. The contents were cooled, diluted with $400 \mathrm{ml}$ of distilled water and transferred into a distillation flask. Next, $25 \mathrm{ml}$ of $4 \%$ boric acid with methylene red indicator was taken in a conical flask. Approximately $90 \mathrm{ml}$ of $40 \% \mathrm{NaOH}$ was added to the distillation flask. The conical flask was placed below the condenser until $300 \mathrm{ml}$ distillate was collected ${ }^{9}$. The evolved $\mathrm{N}_{2} \%$ was determined by titrating the condensate with $0.1 \mathrm{~N} \mathrm{HCl}$. Percentage protein was calculated by the formula

$$
\text { Nitrogen }(\%)=\frac{\left(\begin{array}{c}
(\text { Sample titre }- \text { blank titre }) \times \\
\text { normality of } \mathrm{HCl} \times 14.01 \times 100
\end{array}\right)}{\left(\begin{array}{c}
\text { Weight of sample } \times \\
\text { aliquot taken for distillation } \times 1000
\end{array}\right)} .
$$

Protein $\%=$ nitrogen $\% \times 6.25$.

Ash content: Approximately $5 \mathrm{~g}$ sample was weighed into a crucible and kept for charring on a hot plate for $2 \mathrm{~h}$. After charring, the sample was kept for ashing in a muffle furnace at $550^{\circ} \pm 2^{\circ} \mathrm{C}$ for $6 \mathrm{~h}$ (ref. 8). Ash content was calculated as
Ash content $=\frac{W_{2}-W_{1}}{S} \times 100$

where $W_{1}$ is the weight of the empty silica crucible $(\mathrm{g})$, $W_{2}$ the weight of the silica crucible and ash $(\mathrm{g})$ and $S$ is the weight of the sample (g).

\section{Physico-chemical analysis}

Flavonoids: Sample $(0.1 \mathrm{~g})$ was extracted with $5 \mathrm{ml}$ of $80 \%$ aqueous ethanol by centrifuging at $6000 \mathrm{rpm}$ for $30 \mathrm{~min}$. Then $0.25 \mathrm{ml}$ of the extract was taken in test tube, to which $1.25 \mathrm{ml}$ distilled water and $0.75 \mathrm{ml}$ of $5 \%$ sodium nitrate were added. After allowing to stand for $5 \mathrm{~min}, 0.15 \mathrm{ml}$ of $10 \%$ aluminum chloride was added and then the mixture was further allowed to stand for $6 \mathrm{~min}$. Next, $0.5 \mathrm{ml}$ of $1 \mathrm{~N} \mathrm{NaOH}$ and $0.275 \mathrm{ml}$ distilled water were added to the test tube and absorbance was measured at $510 \mathrm{~nm}$ using a spectrophotometer. Blank was prepared by taking $80 \%$ ethanol instead of extract and the same procedure was followed as mentioned above. The total flavonoid content was expressed in milligrams of catechin equivalents (CE) per gram of the extract. All the determinations were carried out in triplicate ${ }^{10}$.

Total phenolics content: Sample $(0.1 \mathrm{~g})$ was extracted with $5 \mathrm{ml}$ of $80 \%$ aqueous ethanol by centrifuging at $6000 \mathrm{rpm}$ for $30 \mathrm{~min}$. Supernatant was taken in another test tube and boiled until evaporation. Distilled water $(5 \mathrm{ml})$ was added to the residue and $0.2 \mathrm{ml}$ of the solution was transferred to another test tube and madeup to $3 \mathrm{ml}$, with distilled water. Folin Ciocalteau reagent $(5 \mathrm{ml})$ was added and the solution was kept for 3 min before adding $2 \mathrm{ml}$ of $20 \%$ sodium carbonate to the test tube. The solution was boiled for $1 \mathrm{~min}$ and absorbance was measured at $650 \mathrm{~nm}$ using a spectrophotometer. Blank was prepared using $80 \%$ ethanol. The total phenol content was expressed in milligrams of gallic acid equivalents (GAE) per gram of extract. All the determinations were carried out in triplicate ${ }^{11}$.

Ascorbic acid content: This was determined using 2,6dichlorophenolindophenol dye. Sample (10 g) was extracted in 3\% m-phosphoric acid and titrated with dye to pink colour end-point. Results were expressed as milligrams per $100 \mathrm{~g}$ of sample ${ }^{12}$ and calculated using the formula

Ascorbic acid

$$
=\frac{\text { Titre } \times \text { dye factor } \times \text { volume made up } \times 100}{\text { Aliquot of extract } \times \text { weight of volume of sample }} .
$$

\section{Free-radical scavenging activity}

The DPPH free-radical scavenging method was used to evaluate antioxidant property. Sample $(0.5)$ was taken in 
a test tube and $5 \mathrm{ml}$ of $80 \%$ methanol was added to it. After allowing to stand for $5 \mathrm{~min}, 0.1 \mathrm{ml}$ of the solution was pipetted out into another test tube and $3.9 \mathrm{ml}$ of $1 \mathrm{~nm}$ DPPH solution was added to it. The test tube was kept for $30 \mathrm{~min}$ in dark and absorbance was measured at $517 \mathrm{~nm}$ using a spectrophotometer. Blank was prepared using $80 \%$ ethanol $^{13}$. Inhibition of DPPH free radical (\%) was calculated as

$$
\text { Inhibition }(\%)=\frac{\text { A-control }- \text { A-test }}{\text { A-control }} \times 100 \text {, }
$$

where A-control is the absorbance of the control and A-test is the absorbance of the reaction mixture samples.

All the tests were done in triplicate $(n=3)$ and average values calculated.

\section{Formulation and preparation of hard candy}

The hard candy formulation consisted of water $(22.2 \%)$, sugar $(66.6 \%)$, corn syrup $(11.1 \%)$ and citric acid $(0.1 \%)$ as standard ingredients. Fennel powder was added to the above mixture at an incremental level of $0.5 \mathrm{~g}$, ranging from 0.5 to $8 \mathrm{~g}$, thus making 16 formulations, excluding control (with no fennel powder). Sucrose was dissolved in water and then glucose syrup was added. The mixture was stirred continuously to $143.3^{\circ} \mathrm{C}$, removed from the flame and citric acid and fennel-seed powder were added. The contents were poured into silicon moulds and allowed to cool until they hardened.

\section{Sensory evaluation}

For this, all the concentrations of hard candy made using different percentages of fennel-seed powder were analysed to find the best option. Five parameters, viz. colour and appearance, flavour, body and texture, mouthfeel and overall acceptability were used for sensory evaluation ${ }^{14}$. A nine-point hedonic scale was also used for the evaluation. The sensory panel consisted of 50 (25 males and 25 females; aged 25-40 years) semi-trained healthy individuals from the premises of LPU, Phagwara.

In addition, consumer analysis was carried out separately for the optimized hard candy. The untrained consumer panel consisted of 150 random persons. The same parameters mentioned above were used for the analysis. Hard candy was analysed to determine its commercial acceptability.

\section{Statistical analysis}

The data obtained in this study were subjected to statistical analysis. One-way analysis of variance (ANOVA) was applied and Duncan's multiple range test was employed to analyse the test of significance using SPSS 22.0 software (SPSS Italia, Bologna, Italy).

\section{Results and discussion}

\section{Proximate and physico-chemical properties of fennel-seed powder}

The fennel seeds were powdered and processed (sun- and tray-drying and roasting) before being analysed for their proximate and physico-chemical composition (Table $1)$. There was a significant difference $(P<0.05)$ in moisture, fat, protein, ash and dietary fibre for sun-dried powder, roasted powder and tray-dried powder of fennel seeds.

The physico-chemical properties such as total phenollics, flavonoids, ascorbic acid and antioxidant activity were found to be retained to the highest level in sun-dried samples compared to tray-dried and roasted samples and the values differed significantly $(P<0.05)$. Similar results were found by other authors showing that the thermolabile nature of phenolic compounds degraded upon roasting and tray-drying ${ }^{15}$. They get easily degraded upon heat treatment, and since the temperature in traydrying and roasting is concentrated and relatively higher than that during sun-drying (which is fluctuating), the polyphenolic content is lower in the former. There is a high correlation between phenolic content and antioxidant activity, suggesting that higher the phenolic content, higher will be the antioxidant activity. This accounts for the higher antioxidant activity of sun-dried fennel-seed powder compared to roasted and tray-dried samples ${ }^{16}$. Significant losses of ascorbic acid and total phenolics are due to increase in the drying temperatures ${ }^{17}$ (sun-drying at $30-35^{\circ} \mathrm{C}$, tray-drying at $55^{\circ} \mathrm{C}$ and roasting at $75-$ $80^{\circ} \mathrm{C}$ ). Mild heat treatments have less effect on the volatile components despite their long treatment time, whereas intense treatments have significant effect ${ }^{18}$. From the mean values of proximate analysis for all the three samples, sun-dried powder was found to be the most appropriate for incorporation.

\section{Sensory evaluation of hard candy}

Hard candy samples prepared using sun-dried fennel powder was optimized using sensory evaluation. Sensory properties such as colour and appearance (Figure 1), flavour, body and texture, and overall acceptability of the hard candy were evaluated; Table 2 shows the results. DF1 (hard candy control) scored less, i.e. colour and appearance $(7.5 \pm 0.07)$, flavour $(7.5 \pm 0.07)$, body and texture $(7.5 \pm 0.05)$, mouthfeel $(7.3 \pm 0.08)$ and overall acceptance $(7.6 \pm 0.05)$. There was a significant difference $(P<0.05)$ between DF1 and DF11 in terms of sensory parameters. The acceptability increased as 
Table 1. Proximate and physico-chemical analysis of fennel-seed powder

\begin{tabular}{|c|c|c|c|}
\hline Components & Sun-dried powder & Roasted powder & Tray-dried powder \\
\hline Moisture (g/100 g) & $6.86 \pm 0.35^{\mathrm{a}}$ & $4.92 \pm 0.06^{\mathrm{b}}$ & $5.30 \pm 0.52^{b}$ \\
\hline $\operatorname{Ash}(g / 100 \mathrm{~g})$ & $7.5 \pm 0.45^{\mathrm{a}}$ & $4.1 \pm 0.12^{b}$ & $4.0 \pm 0.31^{\mathrm{b}}$ \\
\hline Carbohydrates (g/100 g) & $60.01 \pm 0.25^{\mathrm{c}}$ & $69.75 \pm 0.35^{\mathrm{b}}$ & $71.49 \pm 0.45^{\mathrm{a}}$ \\
\hline Fat $(\mathrm{g} / 100 \mathrm{~g})$ & $12.90 \pm 0.60^{\mathrm{a}}$ & $9.63 \pm 0.71^{\mathrm{b}}$ & $8.52 \pm 0.49^{\mathrm{cb}}$ \\
\hline Protein $(\mathrm{g} / 100 \mathrm{~g})$ & $12.73 \pm 0.85^{\mathrm{a}}$ & $11.60 \pm 0.42^{b}$ & $10.69 \pm 0.34^{\mathrm{c}}$ \\
\hline Dietary Fibre $(\mathrm{g} / 100 \mathrm{~g})$ & $6.51 \pm 0.34^{\mathrm{a}}$ & $4.35 \pm 0.21^{\mathrm{b}}$ & $4.03 \pm 0.46^{\mathrm{b}}$ \\
\hline Total phenolics (mg/GAE $100 \mathrm{~g}$ ) & $522 \pm 0.04^{\mathrm{a}}$ & $497 \pm 0.06^{\mathrm{b}}$ & $300 \pm 0.07^{\mathrm{c}}$ \\
\hline Flavonoids (mg/CE 100 g) & $606 \pm 0.04^{\mathrm{a}}$ & $564 \pm 0.07^{\mathrm{b}}$ & $492 \pm 0.03^{\mathrm{c}}$ \\
\hline Vitamin $C(\mu \mathrm{g} / 100 \mathrm{~g})$ & $325 \pm 0.07^{\mathrm{a}}$ & $217 \pm 0.04^{\mathrm{b}}$ & $209 \pm 0.05^{\mathrm{b}}$ \\
\hline Antioxidant activity (\%) & $22.70 \pm 0.06^{\mathrm{a}}$ & $19.43 \pm 0.05^{\mathrm{c}}$ & $20.29 \pm 0.04^{\mathrm{b}}$ \\
\hline
\end{tabular}

All values are calculated in triplicate $(n=3)$. Values are represented as mean \pm standard deviation. Values represented with different superscripts differ significantly in a column $(P<0.05)$.

the concentration of fennel powder increased till DF11. As the concentration increased further, the sensory parameters were affected. This may be due to the strong aroma and bitter taste of fennel at higher concentration, which was not preferred by the panelists. The texture was also affected at higher concentrations. It has been reported that with increase in the concentration of fennel powder, its sensory parameters are affected owing to its strong aroma and the taste was affected due to bitterness ${ }^{19}$. Colour of a food product is an essential component that determines the quality and its acceptance by the consumers. Visual appearance is the primary factor to evaluate the quality of food. DF11 scored higher in colour and appearance than the other combinations. Taste or flavour is one of the main determinants of food quality ${ }^{20}$. Highest value against hard candy flavour was observed for DF11 with the addition of $5 \%$ fennel powder, while the lowest was obtained for DF16 and DF17 with the addition of $7.5 \%$ and $8 \%$ fennel powder respectively. This is because at concentrations of $7.5 \%$ and $8 \%$, the candy becomes bitter. Texture is a quality parameter that affects the overall acceptability of the product ${ }^{21}$. Highest value against hard candy texture was obtained for DF11 (5\% fennel powder) and lowest for DF17 ( $8 \%$ fennel powder). The results were similar where higher concentration produced viscous texture ${ }^{20}$. The fennel powder started to give grassy flavour and texture, which affected its mouthfeel. For general acceptability, this indicated that DF11 was accepted by the panelists followed by DF1, while the least accepted was DF17 with an overall acceptability of $5.9 \pm 0.09$. The higher the concentration of fennel powder (DF17), lower is the preference level of consumers. This is because at $8 \%$ fennel powder concentration, the hard candy has a dark colour, bitter taste and viscous texture. DF11 was the most accepted formulation (hard candy with 5\% fennel powder) ranking highest according to the colour and appearance $(8.1 \pm 0.07)$, flavour $(8.1 \pm 0.06)$, body and texture $(8.1 \pm 0.05)$, mouthfeel $(8.0 \pm 0.06)$, and overall acceptance $(8.2 \pm 0.05)$.

Table 3 represents data obtained by a consumer study of the best chosen sample of hard candy on the basis of sensory evaluation. Overall acceptability is the clear indication of consumer behaviour towards the samples. DF1 (control) that scored as colour and appearance $(7.6 \pm 0.08)$, flavour $(7.2 \pm 0.08)$, body and texture $(7.3 \pm 0.07)$, mouthfeel $(7.1 \pm 0.07)$, and overall acceptability $(7.4 \pm 0.06)$ was compared with sample DF11 $(5 \%$ fennel powder) that scored as colour and appearance $(7.7 \pm 0.05)$, flavour $(7.6 \pm 0.06)$, body and texture (7.6 \pm 0.04$)$, mouthfeel $(7.5 \pm 0.07)$, and overall acceptability $(7.7 \pm 0.06)$. There was significant difference $(P<0.05)$ in flavour, body and texture, mouthfeel and overall acceptability, but there was no significant difference in colour and appearance as it is totally dependent on the like/dislike of the panelists.

\section{Proximate and physico-chemical analysis of hard candy}

Figure 2 shows the optimized process for hard candy formation. Table 4 shows the results of proximate composition of hard candy - control and sun-dried powderon the basis of sensory evaluation. The moisture content

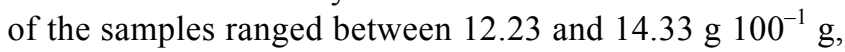
and was not found to be significantly different. The slight difference in moisture may be due to the incorporation of insoluble dietary fibre with fennel powder that absorbs moisture ${ }^{21}$. Control candy had the highest moisture content $\left(14.33 \mathrm{~g} 100^{-1} \mathrm{~g}\right)$. The moisture content of food is significantly important for its general acceptability, shelflife and packaging ${ }^{22}$. High moisture content promotes bacterial growth and thus leads to shorter shelf-life ${ }^{23}$. Hard candy (sun-dried powder) was found to have high ash content $\left(3.2 \pm 0.05 \mathrm{~g} 100^{-1} \mathrm{~g}\right)$, which was significantly different from the control sample. This is due to the fibre content of fennel powder. Furthermore, ash content increases with incorporation of spices due to its mineral content ${ }^{20}$, which can also be observed in the case of fen-

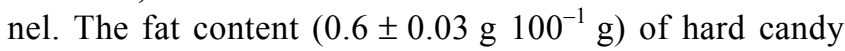
(sun-dried powder) was high compared to that of control. There was significant difference $(P<0.05)$ in fat 
RESEARCH ARTICLES

Table 2. Sensory evaluation of hard candy (sun-dried powder)

\begin{tabular}{|c|c|c|c|c|c|c|}
\hline Sample & $\begin{array}{l}\text { Concentration of } \\
\text { fennel powder }(\%)\end{array}$ & $\begin{array}{l}\text { Colour and } \\
\text { appearance }\end{array}$ & Flavour & $\begin{array}{l}\text { Body and } \\
\text { texture }\end{array}$ & Mouthfeel & $\begin{array}{c}\text { Overall } \\
\text { acceptance }\end{array}$ \\
\hline DF1 & 0 & $7.5 \pm 0.07^{\mathrm{dc}}$ & $7.5 \pm 0.07^{\mathrm{c}}$ & $7.5 \pm 0.05^{\mathrm{d}}$ & $7.3 \pm 0.08^{\mathrm{d}}$ & $7.6 \pm 0.05^{\mathrm{d}}$ \\
\hline DF2 & 0.5 & $7.1 \pm 0.08^{\mathrm{g}}$ & $7.1 \pm 0.08^{\mathrm{e}}$ & $7.0 \pm 0.06^{\mathrm{f}}$ & $7.0 \pm 0.07^{\mathrm{e}}$ & $7.1 \pm 0.06^{\mathrm{f}}$ \\
\hline DF3 & 1 & $7.3 \pm 0.09^{\mathrm{e}}$ & $7.1 \pm 0.01^{\mathrm{f}}$ & $7.3 \pm 0.06^{\mathrm{e}}$ & $7.1 \pm 0.09^{\mathrm{e}}$ & $7.3 \pm 0.07^{\mathrm{e}}$ \\
\hline DF4 & 1.5 & $7.3 \pm 0.06^{\mathrm{e}}$ & $7.3 \pm 0.07^{\mathrm{d}}$ & $7.4 \pm 0.06^{\mathrm{e}}$ & $7.4 \pm 0.07^{\mathrm{cd}}$ & $7.4 \pm 0.05^{\mathrm{e}}$ \\
\hline DF5 & 2 & $7.3 \pm 0.07^{\mathrm{e}}$ & $7.1 \pm 0.07^{\mathrm{ef}}$ & $7.4 \pm 0.08^{\mathrm{e}}$ & $7.0 \pm 0.07^{\mathrm{e}}$ & $7.3 \pm 0.05^{\mathrm{e}}$ \\
\hline DF7 & 3 & $7.1 \pm 0.08^{\mathrm{g}}$ & $7.1 \pm 0.07^{\mathrm{e}}$ & $7.3 \pm 0.07^{\mathrm{e}}$ & $7.2 \pm 0.06^{\mathrm{de}}$ & $7.4 \pm 0.07^{\mathrm{e}}$ \\
\hline DF8 & 3.5 & $7.5 \pm 0.07^{\mathrm{dc}}$ & $7.2 \pm 0.06^{\mathrm{df}}$ & $7.7 \pm 0.06^{\mathrm{cbd}}$ & $7.5 \pm 0.07^{c}$ & $7.5 \pm 0.05^{\mathrm{de}}$ \\
\hline DF9 & 4 & $7.6 \pm 0.06^{\mathrm{c}}$ & $7.4 \pm 0.07^{\mathrm{c}}$ & $7.6 \pm 0.05^{\mathrm{dc}}$ & $7.7 \pm 0.06^{\mathrm{b}}$ & $7.8 \pm 0.04^{\mathrm{c}}$ \\
\hline DF 10 & 4.5 & $7.9 \pm 0.06^{\mathrm{b}}$ & $7.8 \pm 0.06^{\mathrm{b}}$ & $7.8 \pm 0.06^{\mathrm{bc}}$ & $7.8 \pm 0.06^{\mathrm{b}}$ & $7.9 \pm 0.05^{b c}$ \\
\hline DF11 & 5 & $8.1 \pm 0.07^{\mathrm{a}}$ & $8.1 \pm 0.06^{\mathrm{a}}$ & $8.1 \pm 0.05^{\mathrm{a}}$ & $8.0 \pm 0.06^{\mathrm{a}}$ & $8.2 \pm 0.05^{\mathrm{a}}$ \\
\hline DF12 & 5.5 & $7.3 \pm 0.08^{\mathrm{e}}$ & $7.2 \pm 0.09^{\mathrm{df}}$ & $7.3 \pm 0.06^{\mathrm{e}}$ & $7.4 \pm 0.07^{\mathrm{cd}}$ & $7.5 \pm 0.07^{\mathrm{de}}$ \\
\hline DF13 & 6 & $7.2 \pm 0.09^{\mathrm{fe}}$ & $7.1 \pm 0.08^{\mathrm{e}}$ & $7.3 \pm 0.09^{\mathrm{e}}$ & $7.2 \pm 0.08^{\mathrm{de}}$ & $7.3 \pm 0.06^{\mathrm{e}}$ \\
\hline DF15 & 7 & $7.1 \pm 0.08^{\mathrm{g}}$ & $7.1 \pm 0.08^{\mathrm{e}}$ & $7.0 \pm 0.06^{\mathrm{f}}$ & $7.0 \pm 0.07^{\mathrm{e}}$ & $7.1 \pm 0.06^{\mathrm{f}}$ \\
\hline DF16 & 7.5 & $6.1 \pm 0.07^{\mathrm{h}}$ & $6.3 \pm 0.06^{\mathrm{h}}$ & $6.4 \pm 0.08^{g}$ & $6.5 \pm 0.06^{\mathrm{f}}$ & $6.5 \pm 0.06^{\mathrm{g}}$ \\
\hline DF17 & 8 & $5.8 \pm 0.01^{\mathrm{i}}$ & $6.3 \pm 0.07^{\mathrm{h}}$ & $4.2 \pm 0.07^{\mathrm{h}}$ & $5.0 \pm 0.09^{\mathrm{g}}$ & $5.7 \pm 0.09^{\mathrm{h}}$ \\
\hline
\end{tabular}

DF1-0\% FP; DF2-0.5\% FP; DF3-1\% FP; DF4-1.5\% FP; DF5-2\% FP; DF6-2.5\% FP; DF7-3\% FP; DF8-3.5\% FP; DF9-4\% FP; DF10-4.5\% FP; DF11-5\% FP; DF12-5.5\% FP; DF13-6\% FP; DF14-6.5\% FP; DF15-7\% FP; DF16-7.5\% FP; DF17-8\% FP.

Means of ratings by 50 panelists using a descriptive sensory scale $(n=50)$. Values are represented as mean \pm standard deviation. Values represented with different superscripts differ significantly in a column $(P<0.05)$.

Table 3. Analysis of consumer behaviour regarding hard candy of fennel

\begin{tabular}{lcccccc}
\hline Sample & Concentration (\%) & Colour and appearance & Flavour & Body and texture & Mouthfeel & Overall acceptance \\
\hline DF1 & 0 & $7.6 \pm 0.08^{\mathrm{a}}$ & $7.2 \pm 0.08^{\mathrm{b}}$ & $7.3 \pm 0.07^{\mathrm{b}}$ & $7.1 \pm 0.07^{\mathrm{b}}$ & $7.4 \pm 0.06^{\mathrm{b}}$ \\
DF11 & 5 & $7.7 \pm 0.05^{\mathrm{a}}$ & $7.6 \pm 0.06^{\mathrm{a}}$ & $7.6 \pm 0.04^{\mathrm{a}}$ & $7.5 \pm 0.07^{\mathrm{a}}$ & $7.7 \pm 0.06^{\mathrm{a}}$ \\
\hline
\end{tabular}

DF1-0\% FP; DF11-5\% FP. Means of ratings by 150 panelists using a descriptive sensory scale $(n=150)$. Values are represented as mean \pm standard deviation. Values represented with different superscripts differ significantly in a column $(P<0.05)$.
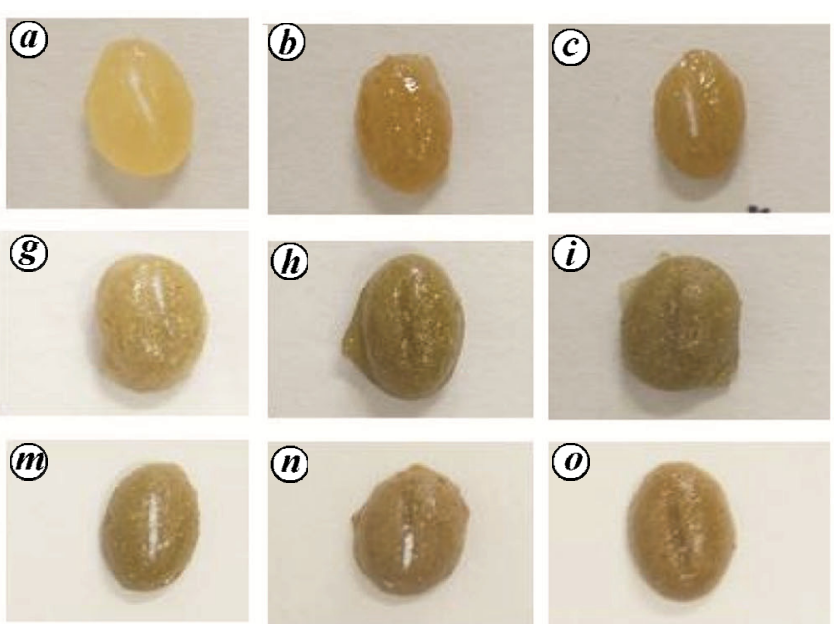
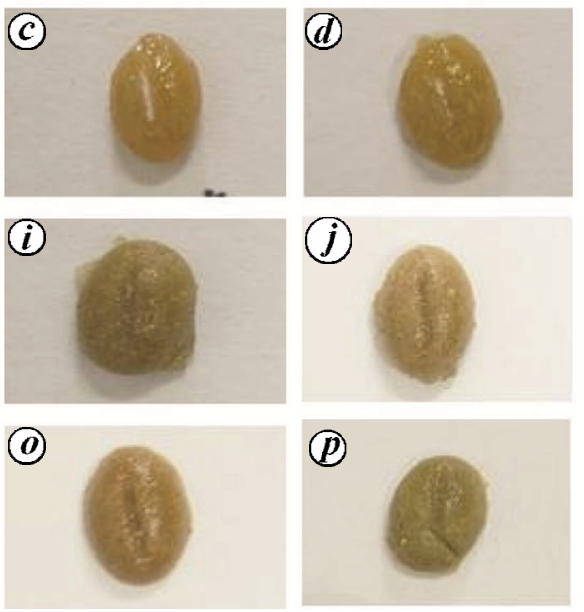
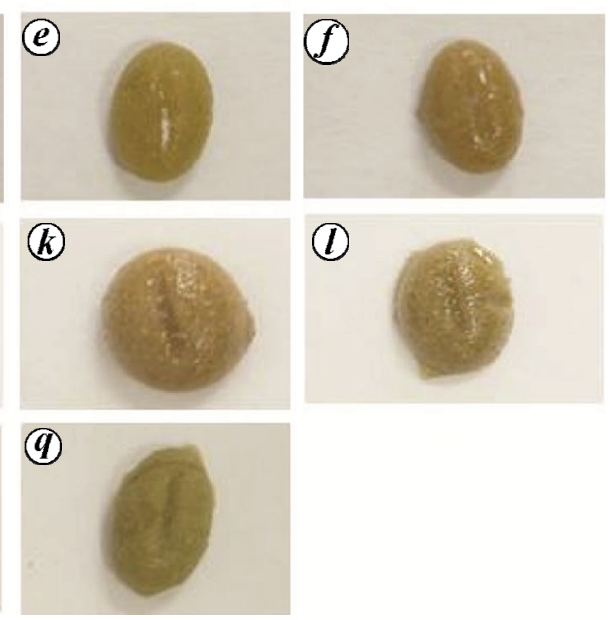

Figure 1. Visual appearance of hard candy with increment in fennel powder (FP) concentration. (a) DF1 (control), (b) DF2 (0.5\% fennel powder), (c) DF3 (1\% FP), (d) DF4 (1.5\% FP), (e) DF5 (2\% FP), (f) DF6 (2.5\% FP), (g) DF7 (3\% FP), (h) DF8 (3.5\% FP), (i) DF9 (4\% FP), (j) DF10 $(4.5 \%$ FP), $(\boldsymbol{k})$ DF11 (5\% FP), (l) DF12 (5.5\% FP), (m) DF13 (6\% FP), (n) DF14 (6.5\% FP), (o) DF15 (7\% FP), (p) DF16 (7.5\% FP) and (q) DF17 $(8 \% \mathrm{FP})$.

content of the samples. The protein content $(1.2 \pm 0.01 \mathrm{~g}$ $100^{-1} \mathrm{~g}$ ) of hard candy (sun-dried powder) was significantly $(P<0.05)$ higher than that of control. Protein content was found to be lower in the final product as compared to that in the sun-dried powder due to the less amount of fennel powder incorporated in the final hardcopy. Results were in accordance with tomato candy prepared by Hasanuzzaman et al. ${ }^{24}$. The carbohydrates 
Table 4. Proximate and physico-chemical analysis of hard candy

\begin{tabular}{lcc}
\hline Components & Control & Hard candy (sun-dried powder) \\
\hline Moisture $(\mathrm{g} / 100 \mathrm{~g})$ & $14.33 \pm 1.52^{\mathrm{A}}$ & $12.23 \pm 1.23^{\mathrm{A}}$ \\
Ash $(\mathrm{g} / 100 \mathrm{~g})$ & $2.2 \pm 0.02^{\mathrm{B}}$ & $3.2 \pm 0.05^{\mathrm{A}}$ \\
Carbohydrates $(\mathrm{g} / 100 \mathrm{~g})$ & $83.47 \pm 0.45^{\mathrm{A}}$ & $82.77 \pm 0.45^{\mathrm{A}}$ \\
Fat $(\mathrm{g} / 100 \mathrm{~g})$ & 0.00 & $0.6 \pm 0.03^{\mathrm{A}}$ \\
Protein $(\mathrm{g} / 100 \mathrm{~g})$ & 0.00 & $1.2 \pm 0.01^{\mathrm{A}}$ \\
Dietary Fibre $(\mathrm{g} / 100 \mathrm{~g})$ & 0.00 & $2.09 \pm 0.09^{\mathrm{A}}$ \\
Total phenolics $(\mathrm{mg} / \mathrm{GAE} 100 \mathrm{~g})$ & 0.00 & $373 \pm 0.60^{\mathrm{A}}$ \\
Flavonoids $(\mathrm{mg} / \mathrm{CE} 100 \mathrm{~g})$ & 0.00 & $243 \pm 1.3^{\mathrm{A}}$ \\
Vitamin C $(\mu \mathrm{g} / 100 \mathrm{~g})$ & 0.00 & $229 \pm 0.5^{\mathrm{A}}$ \\
Antioxidant activity $(\%)$ & 0.00 & $16.6 \pm 0.23^{\mathrm{A}}$ \\
\hline
\end{tabular}

All values are calculated in triplicate $(n=3)$. Values are represented as mean \pm standard deviation. Values represented with different superscripts differ significantly in a row $(P<0.05)$. GAE, Gallic acid equivalents; $\mathrm{CE}$, Catechin equivalents.

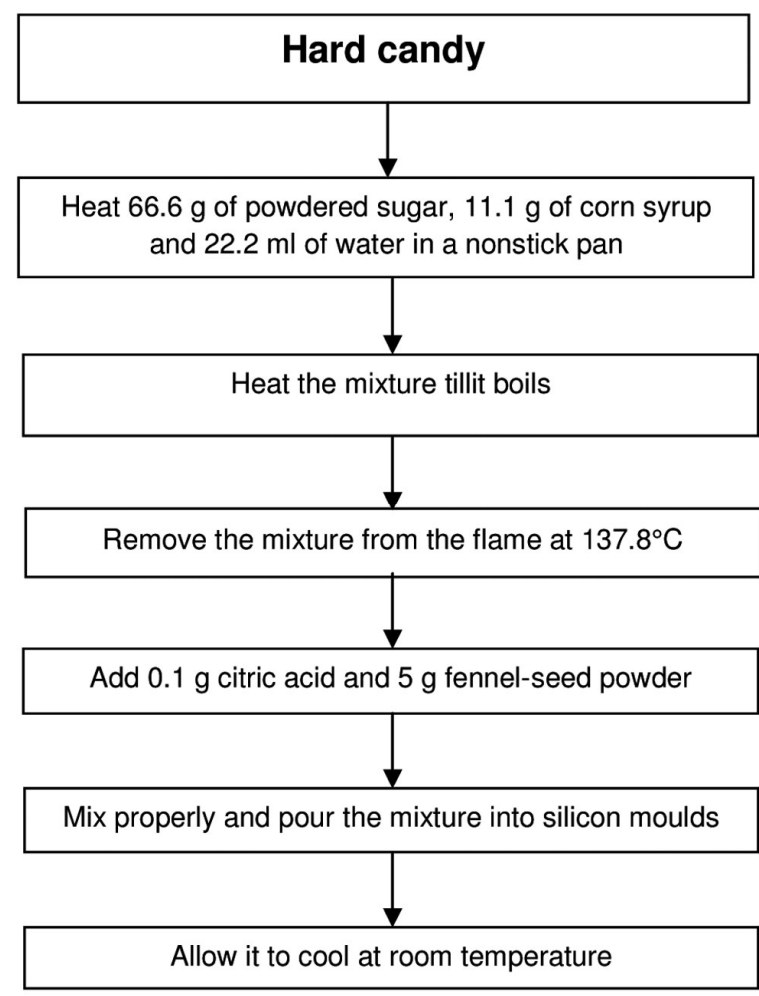

Figure 2. Optimized process for hard candy formation.

content of the final product $(82.77 \pm 0.45)$ was lower than that of control $(83.47 \pm 0.45)$, but the difference was not significant. Dietary fibre $\left(2.09 \pm 0.09 \mathrm{~g} 100^{-1} \mathrm{~g}\right)$ of hard candy was significantly different $(P<0.05)$ from the control. Fibre content was found to be higher as the powder incorporated was of $300 \mu \mathrm{m}$ size. The total phenolics content $\left(373 \pm 0.60 \mathrm{~g} 100^{-1} \mathrm{~g}\right)$ was found to be higher than that of the control, but the results obtained were less than those obtained for powder. The decrease was due to the increase in temperature, as phenols are thermo-labile. Significant difference $(P<0.05)$ was seen for both total phenolics and flavonoids. Vitamin $\mathrm{C}$ content $(229 \pm 0.5 \mu \mathrm{g}$
$100^{-1} \mathrm{~g}$ ) of hard candy (sun-dried powder) was significantly higher than that in the control. Vitamin $\mathrm{C}$ content of sun-dried fennel powder was higher than that of the final product ${ }^{5}$. It was found that vitamin $\mathrm{C}$ content in the candy was good enough to serve as food material to humans ${ }^{25}$. Antioxidants were found to be higher in the powder-incorporated candy; this is because of concentration of fennel powder in it. Similar data have been presented in another study ${ }^{26}$. A significant difference $(P<0.05)$ was seen in hard candy (sun-dried powder) and control.

\section{Conclusion}

Fennel has been a part of the traditional diet of many people, but neglected as a nutritional source. In this study, the best method for the drying of fennel seeds is explored, which will be useful for the production of other value-added products. Sun-drying is the most effective method for the drying of fennel seeds as it conserves most of its nutrients, needs no technical equipment and is economical. The heat treatment in sun-drying is less compared to tray-drying and roasting, though the treatment time period is more. The powder from the sundrying method was used in the formulation of hard candy and the most acceptable formulation was identified (DF11; 5\% fennel powder). The proximate and physicochemical analysis of DF1 (control) and DF11 showed that there was significant difference in the functional and nutritional properties. Therefore, mere incorporation of $5 \%$ fennel could increase the associated benefits to human health.

Conflict of interest: The authors declare no conflict of interest.

1. Bukhari, H., Shehzad, A., Saeed, K., Sadiq, B. M., Tanveer, S. and Iftikhar, T., Compositional profiling of fennel seed. Pak. J. Food. Sci., 2014, 24(3), 132-136. 
2. Coşge, B., Kiralan, M. and Gürbüz, B., Characteristics of fatty acids and essential oil from sweet fennel (Foeniculum vulgare Mill. var. dulce) and bitter fennel fruits (F. vulgare Mill. var. vulgare) growing in Turkey. Nat. Prod. Res., 2008, 22(12), 10111016 .

3. Malhotra, S. K., Fennel and Fennel seed. In Handbook of Herbs and Spices, Woodhead Publishing, 2012.

4. Zheljazkov, V. D., Horgan, T., Astatkie, T. and Schlegel, V., Distillation time modifies essential oil yield, composition, and antioxidant capacity of fennel (Foeniculum vulgare Mill). J. Oleo Sci., 2013, 62(9), 665-672.

5. Badgujar, S. B., Patel, V. V. and Bandivdekar, A. H., Foeniculum vulgare Mill: a review of its botany, phytochemistry, pharmacology, contemporary application, and toxicology. Biomed. Res. Int., 2014, 2014, 1-32.

6. Dua, A., Mittal, A., Gupta, S. and Mahajan, R., Bioreactive and antioxidant properties of methanolic extract of fennel (Foeniculum vulgare). Int. Res. J. Pharm., 2013, 4(5), 241-245.

7. Shahat, A. A., Ibrahim, A. Y., Hendawy, S. F., Omer, E. A., Hammouda, F. M., Abdel Rahman, F. H. and Saleh, M. A., Chemical composition, antimicrobial and antioxidant activities of essential oils from organically cultivated fennel cultivars. Molecules, 2011, 16(2), 1366-1377.

8. AOAC, Official Methods of Analysis of the AOAC International, Association of Official Agricultural Chemists, Washington, USA, 2004, 18th edn.

9. Rasane, P., Jha, A. and Sharma, N., Predictive modelling for shelf life determination of nutricereal based fermented baby food. $J$. Food Sci. Technol., 2015, 52(8), 5003-5011.

10. Samatha, T., Shyamsundarachary, R., Srinivas, P. and Swamy, N. R., Quantification of total phenolic and total flavonoid contents in extracts of Oroxylumindicum L. Kurz. Asian J. Pharm. Clin. Res., 2012, 5(4), 177-179.

11. Kamtekar, S., Keer, V. and Patil, V., Estimation of phenolic content, flavonoid content, antioxidant and alpha amylase inhibitory activity of marketed polyherbal formulation. J. Appl. Pharm. Sci., 2014, 4(9), 61.

12. Ranganna, S., Handbook of Analysis and Quality Control for Fruit and Vegetable Products, Tata McGraw-Hill Education, New Delhi, 2016.

13. Anwar, F., Ali, M., Hussain, A. I. and Shahid, M., Antioxidant and antimicrobial activities of essential oil and extracts of fennel (Foeniculum vulgare Mill.) seeds from Pakistan. Flavour Fragr. J., 2009, 24(4), 170-176.

14. Obasi, N. E., Okorocha, C. and Orisakwe, O. F., Production and evaluation of velvet tamarind (Dialium guineese wild) candy. Eur. J. Food Sci. Technol., 2013, 1(1), 1-8.

15. Trendafilova, A., Todorova, M., Vassileva, E. and Ivanova, D., Comparative study of total phenolic content and radical scaveng- ing activity of conventionally and organically grown herbs. Bot. Serb., 2010, 34(2), 133-136

16. Lemos, M. R. B., de Almeida Siqueira, E. M., Arruda, S. F. and Zambiazi, R. C., The effect of roasting on the phenolic compounds and antioxidant potential of baru nuts (Dipteryx alata Vog.). Food Res. Int., 2012, 48(2), 592-597.

17. Hamrouni-Sellami, I., Rahali, F. Z., Rebey, I. B., Bourgou, S., Limam, F. and Marzouk, B., Total phenolics, flavonoids, and antioxidant activity of sage (Salvia officinalis L.) plants as affected by different drying methods. Food Bioprocess. Technol., 2013, 6(3), $806-817$.

18. An, K., Zhao, D., Wang, Z., Wu, J., Xu, Y. and Xiao, G., Comparison of different drying methods on Chinese ginger (Zingiber officinale Roscoe): changes in volatiles, chemical profile, antioxidant properties, and microstructure. Food Chem., 2016, 197, 1292 1300.

19. Das, L., Raychaudhuri, U. and Chakraborty, R., Herbal fortification of bread with fennel seeds. Food Technol. Biotechnol., 2013, 51(3), 434.

20. Akib, N. I., Baane, W. and Fristiohady, A., Formulation of herbal hard candy contains red ginger (Zingiber officinale var. rubrum) extract. JF FIK UINAM, 2017, 4(1), 1-8.

21. Haruna, M., Udobi, C. E. and Ndife, J., Effect of added brewers dry grain on the physico-chemical, microbial and sensory quality of wheat bread. Am. J. Food Nutr., 2011, 1(1), 39-43.

22. Okaka, J. C. and Okaka, A. N. C., Food Composition, Spoilage and Shelf Life Extension, OCJANCO Acad. Publishers, Enugu, Nigeria, 2001, pp. 225-226.

23. Sayed-Ahmad, B., Straumīte, E., Sabovics, M., Krūma, Z., Merah, O., Saad, Z. and Talou, T., Effect of addition of fennel (Foeniculum vulgare L.) on the quality of protein bread. Proc. Latvian Acad. Sci. B, 2017, 71(6), 509-514.

24. Hasanuzzaman, M., Kamruzzaman, M., Islam, M. M., Khanom, S. A. A., Rahman, M. M., Lisa, L. A. and Paul, D. K., A study on tomato candy prepared by dehydration technique using different sugar solutions. Food Nutr. Sci., 2014, 5(13), 1261.

25. Padayatty, S. J., Katz, A., Wang, Y., Eck, P., Kwon, O., Lee, J. H. and Levine, M., Vitamin $\mathrm{C}$ as an antioxidant: evaluation of its role in disease prevention. J. Am. Coll. Nutr., 2003, 22(1), 18-35.

26. Caleja, C., Barros, L., Antonio, A. L., Ciric, A., Soković, M., Oliveira, M. B. P. and Ferreira, I. C., Foeniculum vulgare Mill. as natural conservation enhancer and health promoter by incorporation in cottage cheese. J. Funct. Food., 2015, 12, 428-438.

Received 27 December 2018; accepted 27 February 2019

doi: $10.18520 / \mathrm{cs} / \mathrm{v} 116 / \mathrm{i} 12 / 2013-2019$ 